Report No.

ER-B-96-01
U.S. Department of Inergy

Office of Inspector General

Report on

\title{
Audit of Work Force \\ Restructuring at the \\ Fernald Invironmental \\ Management Project
}

\section{MASTER}

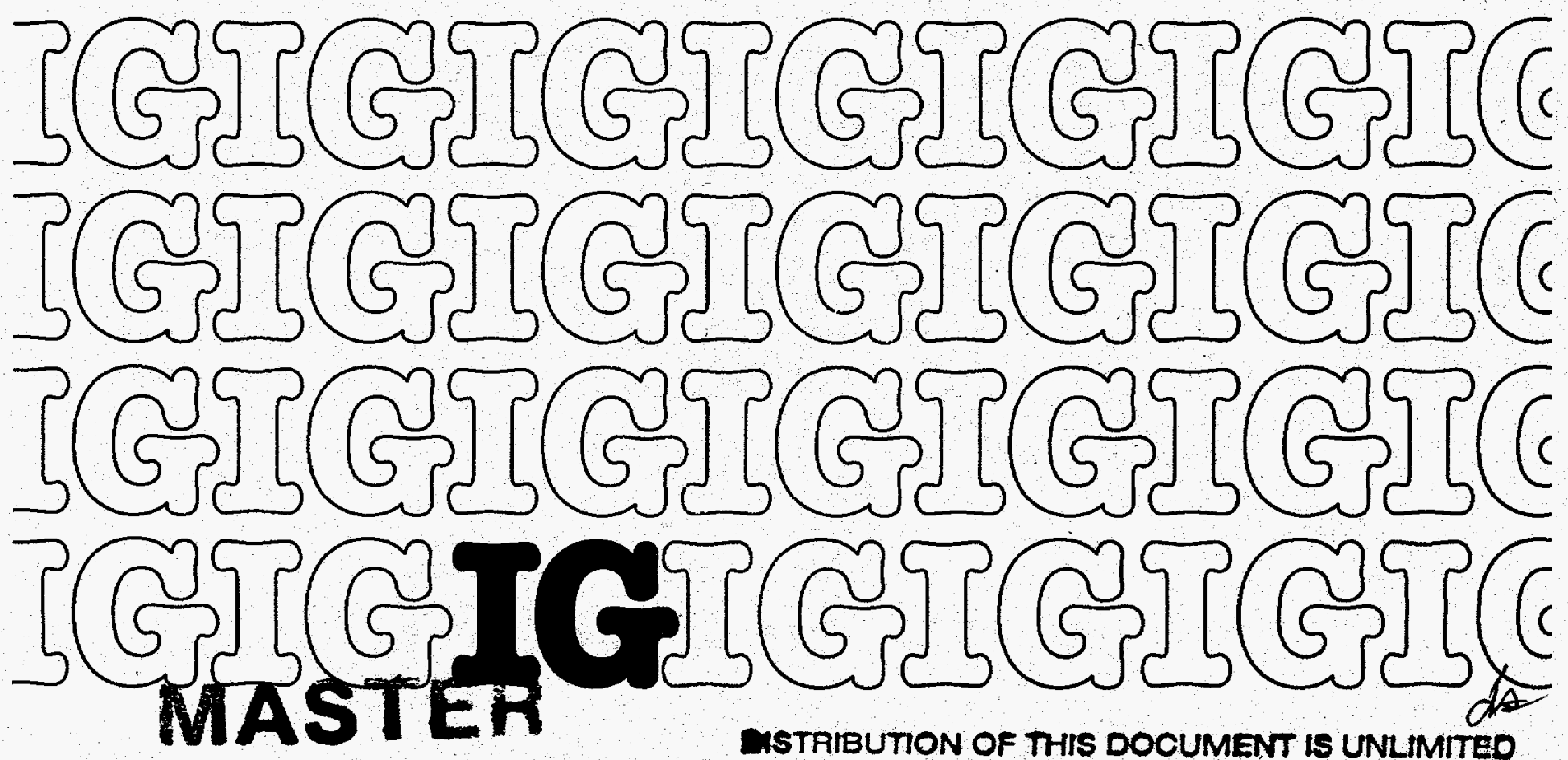


The Office of Inspector General wants to make the distribution of its reports as customer friendly and cost effective as possible. Therefore, this report will be available electronically through the Internet five to seven days after publication at the following alternative addresses:

Department of Energy Headquarters Gopher gopher.hr.doe.gov

Department of Energy Headquarters Anonymous FTP vml.hqadmin.doe.gov

Department of Energy Human Resources and Administration Home Page

http://ww.hr.doe.gov/refshelf.html

Your comments would be appreciated and can be provided on the Customer Response Form attached to the report.

This report can be obtained from the

U.S. Department of Energy

office of Scientific and Technical Information P.0. Box 62

Oak Ridge, Tennessee 37831 


\section{DISCLAMMER}

Portions of this document may be illegible in electronic image products. Images are produced from the best available original document. 
U.S. Department of Energy

Office of Inspector General 


\author{
AUDIT OF WORK FORCE \\ RESTRUCTURING AT THE FERNALD \\ ENVIRONMENTAL MANAGEMENT PROJECT
}

\title{
TABLE OF CONTENTS
}

\section{$\underline{\text { Page }}$}

SUMMARY $\ldots \ldots \ldots \ldots \ldots \ldots \ldots \ldots \ldots \ldots \ldots \ldots$

PART I - $\quad$ APPROACH AND OVERVIEW $\ldots \ldots \ldots \ldots \ldots \ldots \ldots$

Introduction $\ldots \ldots \ldots \ldots \ldots \ldots \ldots \ldots \ldots \ldots \ldots \ldots$

Scope and Methodology $\ldots \ldots \ldots \ldots \ldots \ldots \ldots \ldots \ldots$

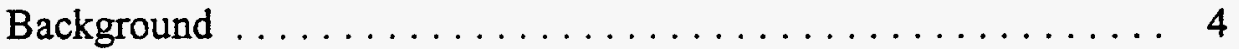

Observations and Conclusions $\ldots \ldots \ldots \ldots \ldots \ldots \ldots \ldots$

PART II - $\quad$ FINDING AND RECOMMENDATIONS $\ldots \ldots \ldots \ldots \ldots \ldots 7$

Restructuring Objectives Not Achieved $\ldots \ldots \ldots \ldots \ldots \ldots \ldots \quad 7$

PART III - MANAGEMENT AND AUDITOR COMMENTS . . . . . . . . 13

PART IV - EXHIBIT - Employees Separated and Hired as of October 3, 1995 


\title{
U.S. DEPARTMENT OF ENERGY \\ OFFICE OF INSPECTOR GENERAL \\ OFFICE OF AUDIT SERVICES
}

\begin{abstract}
AUDIT OF WORK FORCE RESTRUCTURING AT THE FERNALD ENVIRONMENTAL MANAGEMENT PROJECT
\end{abstract}

Audit Report Number: ER-B-96-01

April 23, 1996

\section{$\underline{\text { SUMMARY }}$}

The Department of Energy (Department) restructured its work force at the Fernald Environmental Management Project (Fernald Project) to reduce staffing levels and to modify the mix of workers' skills in response to budget cuts, facility closures, and changes in the Fernald Project's mission. The objective of this audit was to determine whether the work force restructurings were effective in reducing staffing levels and in changing the mix of workers' skills.

As of September 30,1995, the restructurings were not effective in reducing staffing levels or in improving the mix of workers' skills. The Fernald Environmental Restoration Management Corporation (FERMCO) spent $\$ 2.9$ million to separate 255 employees in October 1993. However, by September 30, 1994, all but 14 of the employees separated were either rehired or replaced by new employees with similar skills. The second restructuring began in October 1994 and is not expected to be completed until May 1996. The Department expects the second restructuring to reduce FERMCO's work force by 476 employees at a cost of $\$ 12.9$ million. However, since the second restructuring began, FERMCO has hired 265 new employees and at September 30,1995, had open job announcements seeking 82 additional employees. Many of these new employees have essentially the same skills as employees who separated under the two restructurings.

The Department's objectives were not met because the Fernald Area Office did not (1) require FERMCO to perform the skills analysis necessary to identify which employees were needed to perform the Fernald Project's current mission, and (2) effectively monitor FERMCO's restructuring efforts to ensure that the Department's objectives were met. 
As a result, FERMCO spent $\$ 2.9$ million in Fiscal Year (FY) 1994, and planned to spend an additional $\$ 12.9$ million in FYs 1995 and 1996 for work force restructurings that have provided little or no benefit to the Department.

Management agreed there were some deficiencies in the restructuring process and agreed to implement the recommendations.

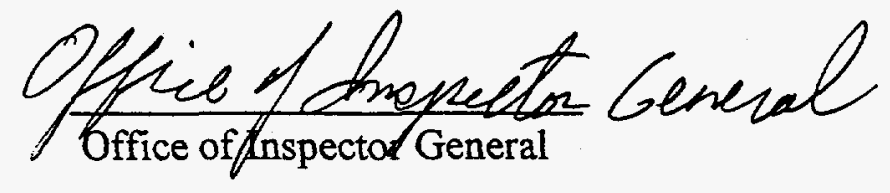




\section{$\underline{\text { PART I }}$}

APPROACH AND OVERVIEW

\section{INTRODUCTION}

Congress directed the Department of Energy (Department), through Public Law 102-484, to minimize the impact of mission changes and associated work force restructurings on affected workers and local communities. In response to this direction, the Department developed guidelines to assist field activities in developing and implementing work force restructuring plans. The first restructuring at the Fernald Environmental Restoration Management Corporation (FERMCO) resulted in the separation of 255 employees in Fiscal Year (FY) 1994 and the second restructuring is expected to reduce the work force by 476 employees by May 1996. These restructurings were planned to reduce staffing levels and change the mix of workers' skills in response to budget cuts, facility shutdowns, and changes in the Fernald Environmental Management Project's (Fernald Project) mission. The objective of the audit was to determine whether the restructurings effectively reduced staffing levels and changed the mix of workers' skills.

\section{SCOPE AND METHODOLOGY}

The audit was performed from January 12,1995 , through October 27, 1995, at the Department's Fernald Area Office and FERMCO in Fernald, Ohio. We also met with the Director, Office of Worker and Community Transition, in Washington, D.C. To achieve the audit objective, we relied on computer-processed data in FERMCO's accounting and human resources information systems. We assessed the accuracy and reliability of the data and found it adequate for use in meeting the audit objective. In addition, we:

- reviewed the requirements of Section 3161 of the National Defense Authorization Act of FY 1993;

- reviewed the Department's work force restructuring guidelines established by the Office of Worker and Community Transition;

- evaluated the development and implementation of the Fernald Area Office's first and second work force restructuring plans;

- analyzed restructuring costs incurred by FERMCO in FYs 1994 and 1995;

- compared staffing levels before and after the restructurings; and 
- compared job titles of the employees separated to those of employees hired during the restructurings.

The audit was performed in accordance with generally accepted Government auditing standards for performance audits and included tests of internal controls and compliance with laws and regulations necessary to satisfy the audit objective. Accordingly, we assessed Departmental policies, procedures, and responsibilities for work force restructuring actions. Because our review was limited, it would not necessarily have disclosed all internal control deficiencies that may have existed at the time of our audit.

The audit results were discussed with the Director, Office of Worker and Community Transition, on February 16, 1996, and an exit conference was held with the Director, Fernald Area Office, on February 21, 1996.

\section{BACKGROUND}

FERMCO operates the Fernald Project under a cost-plus-award-fee contract awarded by the Oak Ridge Operations Office and administered by the Ohio Field Office and the Fernald Area Office. FERMCO assumed responsibility for the Fernald Project on December 1, 1992. From 1952 to 1989, the Fernald Project produced a variety of uranium products that served as feed materials for defense programs at other Departmental sites. The Department suspended production in 1989, and officially ceased production in June 1991. Since 1989, the primary mission of the Fernald Project has been environmental restoration and cleanup.

Subsequent to the end of the Cold War, Congress enacted legislation which required the Department to minimize the impact of work force restructurings made necessary by the end of the Cold War on affected employees and their local communities. The legislation was Public Law 102-484, Section 3161 (Section 3161), dated October 23, 1992. It required that restructuring be accomplished, when possible, through the use of retraining, early retirement, attrition, and other options that minimize layoffs.

In response to this legislation, the Secretary of Energy established a Task Force on Worker and Community Transition (Task Force) to develop guidelines for Department sites to follow in preparing restructuring plans. The guidelines required field activities to develop restructuring plans and submit them to the Task Force for approval. Further, the guidelines established the role of the Department's field organizations and contractors and suggested that restructuring plans be based on comprehensive skills analyses that identify workers' skills necessary to meet the changing mission. Field activities were encouraged to develop restructuring plans which minimized layoffs through the use of voluntary retirements and separations, retraining and re-employment assistance, and worker reassignments. 
Since enactment of Section 3161, FERMCO in coordination with the Fernald Area Office, has prepared two work force restructuring plans. The first restructuring plan was approved by the Office of Worker and Community Transition (formerly the Task Force) in October 1993. The plan called for the voluntary separation or retirement of 62 FERMCO employees and the involuntary separation of another 198 FERMCO employees in FY 1994. Under this restructuring plan, 255 employees were provided severance payments based on their length of service, medical benefits, outplacement support, and retirement benefits, costing $\$ 2.9$ million. Before the first restructuring, FERMCO had 2,417 employees.

The second restructuring plan was approved by the Office of Worker and Community Transition in February 1995. The plan projected the voluntary separation of about 400 FERMCO employees in FYs 1995 and 1996 at a cost of about $\$ 8.2$ million. However, 476 employees have volunteered to separate, and the Department now estimates the cost of the second restructuring to be about $\$ 12.9$ million. Most of the 476 employees who are currently being separated under the plan will receive an incentive bonus of $\$ 15,000$ in addition to enhanced severance pay.

The Fernald Area Office was responsible for monitoring the restructurings to ensure that FERMCO followed Departmental guidelines.

\section{OBSERVATIONS AND CONCLUSIONS}

The Fernald Area Office's FY 1994 work force restructuring did not accomplish the Department's objectives of reducing total employment and changing the mix of workers' skills. FERMCO spent $\$ 2.9$ million to separate 255 employees in October 1993. However, by September 30, 1994, all but 14 of the employeés separated were either rehired or replaced by new employees with similar skills.

We could not determine whether the second restructuring will achieve the Department's objectives because it will not be completed until May 1996. However, FERMCO continued to hire employees to replace those separated. Since the first restructuring began, FERMCO has hired over 600 new employees. If this pattern continues, the second restructuring, estimated to cost $\$ 12.9$ million, like the first, will not significantly reduce overall staffing or substantially change the mix of workers' skills.

These conditions occurred because the Fernald Area Office (1) did not require FERMCO to perform a work force skills analysis to identify employees needed to meet mission requirements, and (2) did not effectively monitor FERMCO's restructuring efforts to ensure that the Department's objectives were met. As a result, FERMCO spent \$2.9 million in FY 1994, and planned to spend an additional \$12.9 million in FYs 1995 and 1996, for work force restructurings that have provided little or no benefit to the Department. Therefore, we recommended that the Director, Fernald Area Office, require FERMCO to review the skills of employees scheduled to be separated, and encourage 
employees with skills that are needed to retain their jobs. We also recommended that the Fernald Area Office monitor FERMCO's efforts to ensure that the Department's restructuring objectives are effectively met and that employees with needed skills are retained and not separated and replaced.

Continuing to separate and replace employees with needed skills under the restructuring plan is, in our opinion, a material internal control weakness that the Department should consider when preparing the yearend assurance memorandum on internal controls. 
$\underline{\text { PART II }}$

FINDING AND RECOMMENDATIONS

\section{Restructuring Objectives Not Achieved}

\section{FINDING}

The Department's restructuring objectives at the Fernald Project were to reduce staffing levels and change the mix of workers' skills. Although FERMCO separated 255 employees in FY 1994 at a cost of $\$ 2.9$ million, by the end of FY 1994 the work force was reduced by only 14 employees. During this restructuring, FERMCO rehired many workers and hired replacement workers with virtually the same skills as most of the employees who were separated; thus, the work force skills mix was not significantly changed. The Department anticipates that the second restructuring, expected to cost $\$ 12.9$ million, will reduce the work force by 476 employees; however, FERMCO continues to hire replacement workers. This condition exists because the Fernald Area Office (1) did not require FERMCO to perform a skills analysis, and (2) has not effectively monitored FERMCO's restructuring efforts. As a result, the Fernald Area Office spent $\$ 2.9$ million in FY 1994, and plans to spend an additional $\$ 12.9$ million in FYs 1995 and 1996, for work force restructurings that have provided little or no benefit to the Department.

\section{RECOMMENDATIONS}

We recommend that the Director, Fernald Area Office:

(1) Require FERMCO to immediately perform a comprehensive skills analysis, review the skills of employees scheduled to be separated, and encourage employees with skills that are needed to retain their jobs;

(2) Develop future restructuring plans based on comprehensive skills analyses in accordance with Departmental guidance; and

(3) Monitor FERMCO's restructuring activities to ensure that the Department's objectives are met. 


\section{MANAGEMENT REACTION}

Management agreed there were some deficiencies in the FY 1994 restructuring process and concurred with the recommendations. However, management stated that the FY 1995 restructuring would achieve the Department's objectives.

\section{DETAILS OF FINDING}

\section{RESTRUCTURING OBJECTIVES}

The Department's objectives for restructuring the work force at the Fernald Project were to simultaneously reduce staffing and change the mix of workers' skills. The Department expected to decrease FERMCO's overall staffing in response to declining budgets and the shutdown of several Fernald Project facilities. The Department also expected to change the mix of workers' skills as remedial investigations and feasibility studies were completed and the actual clean-up efforts began. More specifically, the Department expected to reduce FERMCO's staffing for environmental sampling and characterization, and to increase staffing for construction management and subcontract administration. At the same time, the Department expected to increase staffing for subcontractors involved in remedial design and construction, since FERMCO's contract precluded its workers from performing these functions. For the second restructuring, the Department also expected to reduce project management and project controls personnel involved in administrative activities.

The Department planned to reduce FERMCO's staffing by at least 660 employees in FYs 1994, 1995, and 1996. In the first restructuring, the Department planned to separate 260 employees in FY 1994, including 62 voluntary separations and retirements and 198 involuntary separations. In the second restructuring, the Department plans to separate at least 400 employees in FYs 1995 and 1996, all by voluntary separations and retirements. FERMCO's notice to employees regarding the voluntary reduction-in-force stated that no replacements would be hired to fill vacated positions.

\section{OBJECTIVES NOT ACHIEVED}

FERMCO's restructuring efforts have not accomplished the Department's objectives. The first restructuring neither significantly reduced staffing nor substantially changed the mix of workers' skills. The second restructuring has not been completed; however, FERMCO has continued the same pattern of hiring employees to replace those separated. Thus, the second restructuring, like the first, might neither reduce overall staffing nor change the mix of workers' skills. 
At the beginning of the first restructuring, FERMCO's total employment was 2,417 and it planned to reduce by 260 . FERMCO separated 255 employees, rehired 73, and replaced most of the separated employees with new employees who had essentially the same skills as those separated. FERMCO did not significantly reduce the number of employees involved in environmental sampling and characterization. Also, FERMCO did not significantly increase the number of employees involved in construction management and subcontract administration. Consequently, at the end of FY 1994, FERMCO had reduced its total employment by only 14 and had essentially the same mix of workers' skills as before the restructuring.

In the second restructuring, the Department anticipated a reduction of at least 400 workers from FERMCO's employment base of 2,403. This restructuring will not be completed until May 1996; however, FERMCO has continued the same pattern of separating employees with needed skills and hiring replacements. As of

September 30, 1995, FERMCO had separated 249 employees and still had 2,206 employees for a net reduction of 197 . This net reduction was less than the number separated because FERMCO had hired new employees. Many of these new employees had the same general skills as the employees who were separated. Also, FERMCO had open job announcements seeking 82 additional employees as of September 30, 1995.

The Exhibit at Part IV of this report demonstrates that FERMCO's restructurings did not substantially decrease employment levels nor significantly change the mix of workers' skills. The Exhibit lists the number of employees separated in the first restructuring, the number of employees hired after the first restructuring, and the number of employees targeted to be separated in the second restructuring, as of October 3, 1995, for each individual skill title. If the first restructuring had achieved the skill mix changes anticipated by the Department, the Exhibit would show substantial (1) decreases in the skills associated with environmental sampling and characterization, and (2) increases in the skills associated with construction management and subcontract administration. However, the Exhibit shows no such patterns. FERMCO did not target specific skills for employee separations and new hires. Instead, FERMCO separated and then replaced employees with various types of skills. Moreover, for the four skill titles with the most separations in the first restructuring--clerk typists, secretaries, information record clerks/specialists, and information management analysts--the number of new workers hired after the restructuring far exceeded the number of employees separated.

As the following examples show, FERMCO's pattern of separating employees with needed skills and then hiring replacements occurred in both restructuring efforts.

- FERMCO separated 14 secretaries during the first restructuring, but then hired 19 new secretaries before the second restructuring. In the second restructuring, FERMCO identified 47 secretaries for separation, 3 of whom were hired after the first restructuring. Since announcing the second restructuring, FERMCO has hired 19 new secretaries. 
- FERMCO separated 15 clerk typists in the first restructuring and subsequently hired 8 new clerk typists before the second restructuring. In the second restructuring, FERMCO identified 9 clerk typists for separation, 3 of whom were hired after the first restructuring. Since announcing the second restructuring, FERMCO has hired 17 new clerk typists.

- FERMCO separated 12 information records clerks/specialists during the first restructuring and subsequently hired 18 new information records clerks/specialists before the second restructuring. In the second restructuring, FERMCO identified 35 information records clerks/specialists for separation, 7 of whom were hired after the first restructuring. Since announcing the second restructuring, FERMCO has hired 8 new information records clerks/ specialists.

- FERMCO separated 5 procurement specialists during the first restructuring and subsequently hired 9 new procurement specialists before the second restructuring. In the second restructuring, FERMCO identified 8 procurement specialists for separation, 1 of whom was hired after the first restructuring. Since announcing the second restructuring, FERMCO has hired 4 new procurement specialists.

During the audit, we received several formal and informal allegations of improprieties in the FERMCO restructuring processes. Some complainants alleged that workers who were hired by FERMCO's predecessor organizations at the Fernald Project were unfairly targeted for separation and replaced with new hires transferred in from other components of Fluor Daniel, Inc. Others alleged that selected workers were given separation and early retirement benefits for which they were not entitled. We verified that in at least a few instances, workers hired by FERMCO's predecessors were separated and replaced by new hires transferred in from other components of Fluor Daniel, Inc. However, we could not determine, with any degree of certainty, whether the new hires were more qualified or less qualified than the employees separated. Also, we referred an allegation of improper benefit payments to specific workers to the Director, Office of Worker and Community Transition, whose staff is still evaluating the allegation.

Management stated that many of the hirings shown in the Exhibit at Part IV were justified by changes in work scope, natural progression, attrition, and the requirements of the new collective bargaining agreement. Also, management stated that any instance of separating FERMCO employees and replacing them with new hires from other Fluor Daniel, Inc., components may have been totally proper considering the work to be accomplished and the particular skills of the workers involved. Nevertheless, we believe the exhibit strongly suggests a pattern of separating employees with needed skills and hiring replacements with similar skills, with little change in the overall employment level. 
RESTRUCTURING PLANS SUBMITTED WITHOUT SKIILS ANALYSIS

These conditions occurred because the Fernald Area Office did not require FERMCO to perform the skills analysis necessary to identify which employees should be retained and which should be separated. In addition, the Fernald Area Office did not effectively monitor FERMCO's restructuring efforts.

\section{Skills Analysis Not Performed}

Preliminary Departmental guidance, issued in April 1993 and revised in March 1994, suggested that field activities develop restructuring plans based on a comprehensive skills analysis. The analysis was necessary to (1) determine worker skills required for the site mission, (2) compare skills and capabilities of the current work force to future needs, (3) identify worker retraining needs, and (4) identify workers with critical skills that must be retained. However, FERMCO did not perform a skills analysis, and the Fernald Area Office submitted both restructuring plans for Headquarters' approval without identifying the specific occupations or skills titles to be increased or decreased by the restructurings.

In the absence of a skills analysis, FERMCO's staffing reductions were based on collective bargaining agreements for union employees and division managers' rankings for salaried employees. Once Departmental budgets were established, division managers identified and separated hourly employees based on their respective collective bargaining agreements. Additionally, salaried employees were ranked by division managers on factors such as work habits, experience, and support for company values. Employees with the lowest rankings were separated without regard to skills possessed. Consequently, FERMCO separated employees with needed skills and hired new employees to replace those separated.

Despite the lack of a skills analysis, the Fernald Area Office submitted two restructuring plans, anticipating the separation of more than 600 FERMCO employees, for Headquarters' approval. FERMCO provided the Fernald Area office with details of its ranking system for identifying employees to be separated. FERMCO did not propose to identify critical skills needed to meet the Fernald Project's future mission nor to identify employees who could be reassigned or retrained rather than separated. The Fernald Area Office should have determined that the restructuring plans did not meet the basic requirements of Section 3161, especially the requirement to minimize layoffs. It should have required FERMCO to pursue opportunities for employee reassignments and retraining to avoid, or at least minimize, the number of layoffs.

\section{Restructuring Not Effectively Monitored}

After the first restructuring began, the Fernald Area Office did not closely monitor FERMCO's restructuring efforts to ensure that the Department's objectives were met. The Fernald Area Office did not monitor the occupations of workers who were 
separated or hired to ensure that FERMCO (1) reduced the number of workers involved in environmental sampling and characterization, (2) increased the number of workers involved in construction management and subcontract administration, and (3) minimized layoffs by retaining workers with needed skills. The Fernald Area Office did not require periodic status reports on the numbers of employees hired and separated by occupation. Therefore, the Department was not aware that employees with needed skills were continually being separated and replaced.

Even though FERMCO had not completed the second restructuring and its success was questionable, the Fernald Area Office gave FERMCO $\$ 405,000$ in award fee for an "Excellent" rating on its work force restructuring efforts for the 6 months ended September 30, 1994.

\section{LIMITED BENEFITS}

The Fernald Area Office spent $\$ 2.9$ million in FY 1994, and plans to spend an additional $\$ 12.9$ million in FYs 1995 and 1996 for work force restructurings that have provided little or no benefit to the Department. Also, the Fernald Area Office is likely to pay for similar restructurings in future years because FERMCO still has not identified future staffing needs and continues to hire replacements for employees that it separates.

The funds spent on these restructurings, that provided little or no benefit to the Department, cannot be recouped. Nevertheless, this experience should not be repeated. More restructuring will be necessary in the future as the cleanup workload decreases and is ultimately completed. The future expenditures could far exceed the expenditures to date. 


\section{$\underline{\text { PART III }}$}

\section{MANAGEMENT AND AUDITOR COMMENTS}

The Director, Fernald Area Office, and the Director, Office of Worker and Community Transition, responded to a draft of this report. A summary of both responses follows.

The Director, Fernald Area Office agreed that there were some deficiencies in planning and implementing the FY 1994 restructuring effort. Management stated that those deficiencies were the result of budgetary fluctuations, work scope changes, and significant labor relations developments subsequent to implementation of the FY 1994 restructuring plan. However, corrective actions were taken in the FY 1995 restructuring based upon lessons learned in the FY 1994 restructuring. Also the Fernald Area Office took a more active role in implementing the FY 1995 plan. Management stated that the FY 1995 restructuring is clearly meeting the Department's objective for salaried employee reductions. Salaried employment decreased from 1,826 on December 30,1994, to 1,523 on February 9, 1996. The salaried target level for May 30, 1996, is 1,351, and it will be achieved.

The Director, Office of Worker and Community Transition, stated that he has tasked his Deputy Director to thoroughly investigate the issues covered in this report. The Director stated that the investigation has tentatively concluded that (1) satisfactory planning was lacking in the FY 1994 restructuring, (2) certain union employees had to be rehired because of changes in the labor agreement, and (3) some rehiring was necessary because of budget changes during the year or can be explained due to attrition. The Director also stated that the FY 1995 restructuring will meet the planned work force reduction and change the skills mix to place more emphasis on environmental remediation. The Director further stated that he had not received satisfactory information to reach a conclusion on a number of other issues raised in this report.

The Director, Fernald Area Office, agreed to implement the recommendations. Management's comments on each recommendation follow along with auditor comments.

Recommendation 1. Require FERMCO to immediately perform a comprehensive skills analysis, review the skills of employees scheduled to be separated, and encourage employees with skills that are needed to retain their jobs.

Management Comments. Management concurred and stated that it would make every effort to place employees scheduled for separation in appropriate positions before their currently scheduled separation. 
Auditor Comments. Management's corrective actions are appropriate and should result in retaining employees needed for the future and, at the same time, reduce the amount of severance payments.

Recommendation 2. Develop future restructuring plans based on comprehensive skills analyses in accordance with Departmental guidance.

Management Comments. Management agreed with the recommendation and stated that there have been three iterations of FERMCO's skills mix analyses and each resulted in improvements. FERMCO will continue to make improvements.

Auditor Comments. Management's actions should result in the necessary improvements if a comprehensive skills analysis is performed before any future restructurings are implemented.

Recommendation 3. Monitor FERMCO's restructuring activities to ensure that the Department's objectives are met.

Management Comments. Management agreed to continue monitoring work force restructuring activities in a manner consistent with Departmental objectives, related guidance, and funding constraints. Management stated that as part of the lessons learned from the FY 1994 restructuring, it took a much more active role in the implementation of the FY 1995 restructuring plan. All plan contents, particularly the voluntary reduction in force portion, were the product of extensive discussions, and where appropriate, management direction and involvement.

Auditor Comments. Management's actions should result in the needed improvements if additional actions are taken to ensure that employees separated are not replaced with newly hired employees with similar skills. 
Report Number: ER-B-96-01

Exhibit

Page 1 of 4

\section{PART IV}

\section{EMPLOYEES SEPARATED AND HIRED AS OF OCTOBER 3, 1995}

\begin{tabular}{|c|c|c|c|}
\hline & $\begin{array}{l}\text { NUMBER } \\
\text { SEPARATED IN } \\
\text { FIRST }\end{array}$ & NUMBER OF & $\begin{array}{l}\text { NUMBER TO BE } \\
\text { SEPARATED IN } \\
\text { SECOND }\end{array}$ \\
\hline KILLTITLE & RESTRUCTURING & NEW HIRES & RESTRUCTURING \\
\hline
\end{tabular}

ACCOUNTANT I, II, III \& SR \& TECH II ADMNISTRATTVE ASSISTANT

ADMINISTRATIVE SUPERVISOR

ANALYTICAL CHEMIST I, II, III \& SR ASS'T WATER PLANT OPERATOR ASSOC CONSTRUCTION ENGR, I, II ASSOC CONSTRUCTION SUPPORT ENGR, I ASSOC ENGINEER I, II ASSOC INFO MGMT ANALYST/SPECIALIST ASSOC MATERIAL CONTROL SPECIALIST ASSOC PROCESS/SPECIALIST ENGR I, II BOILER OPERATOR

CARPENTER

CLERK TYPIST I, II \& SR CONSTRUCTION ENGR AIDE II CONSTRUCTION ENGR I, II CONSTRUCTION ENGR MGR I CONSTRUCTION MGR I \& SR CONSTRUCTION SUPERINTENDENT II CONSTRUCTION SUPPORT ENGR I, II COOK

CO-OP, INTERN, GRADUATE ASSISTANT COST ANALYST DEPARTMENT ADMINISTRATOR, I, II DIRECTOR OF AUDIT DIRECTOR OF CERCLA/RCRA UNTT DIRECTOR OF ENGINEERING DIRECTOR OF QUALITY DIRECTOR OF STRATEGIC PROGRAMS I DRAFTER III \& SR ELECTRICIAN EMERGENCY RESPONSE PLANNER PRINCIPLE ENGR, ENGNEER I, II \& SR ENGINEERING AIDE I, II, III ENGINEERING COORD II PRINCIPLE ENV/LAB SCIENTIST, I, II, III \& SR ENV/LAB TECHNICLAN I,II, III \& SR ENV PROJECT MGR ENV PROTECTION ENGR/SPECIALIST I, II, III \& SR ENV WASTE ENGR/SPECIALIST I, II, III \& SR

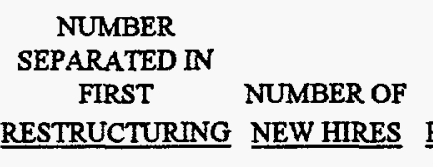

NUMBER TO BE SECOND

\begin{tabular}{|c|c|c|}
\hline 3 & 1 & 3 \\
\hline - & 2 & 5 \\
\hline - & - & 1 \\
\hline 6 & 3 & 7 \\
\hline - & 7 & - \\
\hline 1 & 2 & 2 \\
\hline - & 2 & 2 \\
\hline 7 & 3 & 7 \\
\hline 1 & - & - \\
\hline - & - & 3 \\
\hline 2 & - & 5 \\
\hline - & 1 & - \\
\hline - & 4 & - \\
\hline 15 & 25 & 9 \\
\hline - & 1 & 1 \\
\hline- & 6 & 5 \\
\hline - & - & 3 \\
\hline+ & 3 & 1 \\
\hline - & - & 1 \\
\hline 2 & 2 & - \\
\hline 1 & - & - \\
\hline - & 72 & - \\
\hline- & 1 & 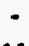 \\
\hline 5 & 3 & 11 \\
\hline- & $\cdot$ & 1 \\
\hline - & 2 & - \\
\hline - & 1 & - \\
\hline- & 1 & - \\
\hline - & 1 & - \\
\hline 1 & 1 & - \\
\hline - & 13 & - \\
\hline 1 & - & - \\
\hline 9 & 8 & 16 \\
\hline 2 & 4 & 4 \\
\hline- & - & 2 \\
\hline 6 & 6 & 41 \\
\hline 2 & 14 & 19 \\
\hline - & 1 & - \\
\hline 2 & 1 & 10 \\
\hline 3 & 5 & 12 \\
\hline
\end{tabular}




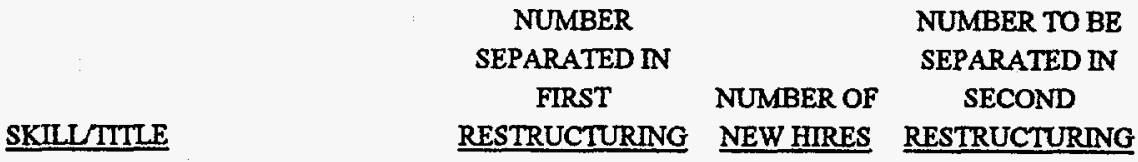

\section{EXECUTIVE VP}

FIRE FIGHTER/ER SPECIALIST II/ PREVENT INSPECT. FIRE PROTECTION ENGR/SPECIALIST I

GENERAL SUPERVISOR

GRAPHICS ARTIST II \& SR

HAZARDOUS WASTE TECH (HAZWAT)

HEALTH PHYSICIST II, III

HEALTH PHYSICS TECHNICIAN III

HR/R TECHNICLAN I II \& SR

HUMAN RESOURCES SPECIALIST I, II, III \& SR

INDUSTRIAL HYGIENE TECHNICIAN I, II, \& SR

INDUSTRIAL HYGIENIST II,III

INDUSTRIAL RELATIONS REP III

INFO MGMT ANALYST/SPECIALIST I, II, III \& SR

INFO MGMT TECHNICIAN I

INFO/RECORDS CLERK \& SPECIALIST I, II, III \& SR

INSTRUMENT MECHANIC

INVENTORY/SUPPLY ANALYST I, SPECIALIST

INVENTORY/SUPPLY SUPERVISOR

LABORER

LAUNDRY WORKER

LEAD INFO MGMT ANALYST/SPECIALIST

LEAD MAILROOM SUPPORT SPECIALIST, L,II

LIBRARY SUPERVISOR

MAINTENANCE PLANNER I \& SUPERVISOR I

MATERIAL COST ESTIMATOR I

MATERIAL CONTROL SPECIALIST I

MGR ADMINISTRATTVE/FACILITY SERVICES, SR MGR

MGR CONTRACT ADMINISTRATION, SR MGR

MGR ENGINEERING

MGR HUMAN RESOURCES

MGR INFO/RECORDS MGMT

MGR MATERIAL C\&A, SR MGR

MGR PUBLIC AFFAIRS

MGR QUALITY, SR MGR

MGR RAD ASSESSMENT

MGR RADIOLOGICAL DOSIMETRY

MGR RSO OPERATIONS

MGR SAFETY ENGINEERING

MGR SECURITY/SECURITY ADMINSTRATOR

MGR SUPPORT SERVICES

MGR TECH PUBLICATIONS

MGR TECHNOLOGY PROGRAMS

MGR UTHLIIIES SERVICES

MGR I, II ANALYTICAL LAB SERVICES

MGR I, II III ENV WASTE MGMT

MGR I INFO SYSTEMS

MGR I II PROGRAM MGMT

MGR I MAINTENANCE SERVICES 


\section{SKILUTTTLE}

NUMBER SEPARATED IN

FIRST

RESTRUCTURING
NUMBER OF

NUMBER TO BE SEPARATED IN SECOND NEW HIRES
RESTRUCTURING

MGR II ENV SCIENCE

MEDICAL TECHNOLOGIST

MILLWRIGHT

MOTOR VEHICLE OPERATOR

OPERATTONS AREA SUPERVISOR

OPERATIONS MGR I, II, III

OPERATIONS SUPERVISOR

PHOTOGRAPHIC TECH

PIPEFITTER

PORTER

PRESIDENT

PRINCIPLE INFO/RECORDS SPECIALIST I, II

PRINCIPLE MATLPROP CNTRL SPECIALIST

PRINCIPLE PROCESS/SPECIALTY ENGR, I, II \& SR

PRINCIPLE PROCUREMENT SPECIALIST, I, II \& SR

PROJECT CTRLS ASSOC I, II

PRINCIPLE PROJECT CTRLS ENGR/SPECIALIST, I, II \& SR

PROJECT ENGR I, II \& SR, PRINC

PROJECT MGR II, III

PUBLIC AFFAIRS SPECIALIST I, II, III \& SR

QUALITY VERIFIER II \& SR

RAD CONTROL TECH I, II, III \& SR

RECEPTIONIST

REG COMPLIANCE ENGR/SPECIALIST, I, II, III

REPRO EQUIPMENT OPERATOR \& SR

SAFETY ENGR/SPECIALIST I, III \& SR

SECRETARY I, II, III \& SR

SECURITY OFFICER

SITE SERVICES SUPERVISOR

SR COMPUTER OPERATOR

SR CONT PERF MP SPECLALIST

SR COUNSEL

SR EMERGENCY PLANNER

SR MGR ACCOUNTING

SR MGR ENV PROTECTION

SR MGR ENV SCIENCE

SR MGR ENV WASTE MGMT

SR MGR INDUSTRIAL RELATIONS

SR MGR PROCUREMENT

SR MGR PROJECT CONTROLS

SR MGR RAD CONTROL

SR MGR STRATEGIC PROGRAMS INT

SR NURSE

SR PHOTOGRAPHIC TECH

SR SUPV ADM/FACILITY SERVICES

SR TECHNICAL MGR

STOREROOM ATTENDANT

SUPPORT SVCS SUPERVISOR I, II

SUPERVISOR ANALYTICAL LAB SVCS 


\section{SKILLTTTLE}

SUPERVISOR ENV SCIENCE SUPERVISOR FIRE PROT ENGINEERING SUPERVISOR INFO MGMT SUPERVISOR INFO/RECORDS MGMT SUPERVISOR PROCUREMENT SUPERVISOR QUALITY SUPERVISOR RAD CONTROL SUPERVISOR TRAINING PRINCIPLE TECH/PROGRAM SPECIALIST, I, II, III \& SR TECH PUBLICATIONS SUPERVISOR TECH WRITER/EDITOR I, II, III TRAFFIC SUPERVISOR

TRANNING COORD

TRAINING SPECIALIST I, II, III \& SR UTHLITIES SVCS SUPERVISOR I

UTTLITY WORKER

WAREHOUSE TECH $\Pi$

WASTE WATER PLANT OPERATOR

WELDER

WELLNESS COORDINATOR

WORD PROCESSING TECH II, III \& SR LONG TERM DISABILTTY

TOTALS
NUMBER SEPARATED NN FIRST RESTRUCTURING
NUMBER OF NEW HIRES
NUMBER TO BE SEPARATED IN SECOND RESTRUCTURNG

\begin{tabular}{ccc}
- & - & 1 \\
- & - & 1 \\
- & - & 1 \\
1 & 1 & 1 \\
1 & $\cdot$ & $\cdot$ \\
- & - & 1 \\
- & 2 & 1 \\
1 & 2 & - \\
8 & 8 & 30 \\
- & - & 1 \\
2 & 6 & 3 \\
- & 1 & 2 \\
- & - & 1 \\
5 & 9 & 7 \\
- & - & 1 \\
3 & - & - \\
- & - & 1 \\
- & 11 & - \\
1 & - & - \\
- & 1 & - \\
4 & 14 & 4 \\
$\cdot$ & - & 1 \\
\hline 255 & 616 & 476 \\
\hline
\end{tabular}


IG Report No. ER-B-96-01

\section{CUSTOMER RESPONSE FORM}

The Office of Inspector General has a continuing interest in improving the usefulness of its products. We wish to make our reports as responsive as possible to our customers' requirements, and therefore ask that you consider sharing your thoughts with us. On the back of this form, you may suggest improvements to enhance the effectiveness of future reports. Please include answers to the following questions if they are applicable to you:

1. What additional background information about the selection, scheduling, scope, or procedures of the audit or inspection would have been helpful to the reader in understanding this report?

2. What additional information related to findings and recommendations could have been included in this report to assist management in implementing corrective actions?

3. What format, stylistic, or organizational changes might have made this report's overall message more clear to the reader?

4. What additional actions could the office of Inspector General have taken on the issues discussed in this report which would have been helpful?

Please include your name and telephone number so that we may contact you should we have any questions about your comments.

Name

Date

Telephone

Organization

When you have completed this form, you may telefax it to the office of Inspector General at (202) 586-0948, or you may mail it to:

Office of Inspector General (IG-I)

Department of Energy

Washington, D.C. 20585

ATTN: Customer Relations

If you wish to discuss this report or your comments with a staff member of the office of Inspector General, please contact Wilma slaughter (202) 586-1924. 